\title{
THE EXISTENCE OF TRADITIONAL LAW REVIEWING FROM PANCASILA VALUES IN THE DEVELOPMENT OF NATIONAL LAW
}

\section{EKSISTENSI HUKUM ADAT DITINJAU DARI NILAI-NILAI PANCASILA DALAM PEMBANGUNAN HUKUM NASIONAL ${ }^{*}$}

\author{
Nova Yarsina \\ Sekolah Tinggi Ilmu Hukum Putri Maharaja Payakumbuh \\ e-mail: novayarsina@yahoo.com
}

\begin{abstract}
The purpose of this study is to examine the existence of customary law in terms of Pancasila values in the development of national law and what factors influence the existence of customary law in terms of Pancasila values in the development of national law. The research method used is normative juridical. The Indonesian people have succeeded in carrying out legal reforms to the constitution. Legal reform must continue with the formation and renewal of laws replacing Dutch legacy laws. Having its own laws for the Indonesian people can reveal national identity. Legal development simply implies efforts to make improvements from unfavorable conditions to better ones. According to this understanding, development can be meaningful with renewal. Reform is an effort to reorient and reform something that will be pursued through policy. The development of national law is the process of building a legal system and its instruments. The development of national law must be able to replace all Dutch Colonial product laws replaced with their own product laws. Legal development cannot be separated from legal politics, because it is a direction in making and enforcing laws in order to achieve national goals and objectives. Law as mentioned in the Oxford English Dictionary is a collection of rules either as a result of formal legislation or custom, in which a certain state or society claims to be bound as members or as subjects. Law is a behavioral control system (ethical control). The legal form is a norm which is the product of a center of power that has the authority to create and apply the law. Law as a unidirectional control system carried out by a central organ that has power. Unidirectional control implies that control only takes place from a certain organ that is given the capacity and function for it. Unidirectional control is also automatic-mechanical that guides behavior.
\end{abstract}

Keywords: Existence; Customary Law; Pancasila; Legal Development.

\section{Abtrak}

Tujuan penelitian ini adalah meneliti eksistensi hukum adat ditinjau dari nilai-nilai pancasila dalam pembangunan hukum nasional dan faktor-faktor apa saja yang mempengaruhi eksistensi hukum adat ditinjau dari nilai-nilai pancasila dalam pembangunan hukum nasional. Metode penelitin yang digunakan adalah yuridis normatif. Bangsa Indonesia sudah berhasil melakukan reformasi hukum terhadap konstitusi. Reformasi hukum harus berlanjut dengan pembentukan dan pembaruan hukum menggantikan hukum peninggalan Belanda. Memiliki hukum sendiri bagi bangsa Indonesia dapat menampakkan jati diri bangsa. Pembangunan hokum secara sederhana mengandung pengertian upaya melakukan perbaikan dari kondisi yang kurang baik menuju ke arah yang lebih baik. Menurut pengertian ini pembangunan bisa semakna dengan pembaharuan. Pembaharuan (reform) merupakan upaya untuk melakukan reorientasi dan reformasi terhadap sesuatu hal yang akan ditempuh melalui kebijakan. Pembangunan hukum nasional merupakan proses membangun suatu tata hukum beserta perangkatnya. Pembangunan hukum nasional harus mampu mengganti semua hukum produk Kolonial Belanda diganti dengan hukum produk sendiri. Pembangunan hukum tidak dapat lepas dari politik hukum, karena sebagai arah dalam pembuatan dan penegakan hukum guna mencapai cita-cita dan tujuan nasional. Hukum seperti yang disebutkan di dalam Oxford English Dictionary yaitu kumpulan aturan baik sebagai

\footnotetext{
* Naskah diterima: 16 September 2021, direvisi: 23 September 2021, disetujui untuk terbit: 29 September 2021

Doi: $10.3376 /$ jch.v7i1.415
} 
Nova Yarsina: Eksistensi Hukum Adat Ditinjau Dari Nilai-Nilai Pancasila Dalam...

hasil pengundangan formal maupun kebiasaan, di mana suatu negara atau masyarakat tertentu mengaku terikat sebagai anggota atau sebagai subyeknya. Hukum merupakan sebuah sistem pengawas perilaku (ethical control). Wujud hukum berupa norma yang merupakan produk dari suatu pusat kekuasaan yang memiliki kewenangan untuk menciptakan dan menerapkan hukum. Hukum sebagai suatu sistem kontrol searah yang dilakukan oleh suatu central organ yang memiliki kekuasaan. Kontrol searah mengandung pengertian bahwa kontrol hanya berlangsung dari suatu organ tertentu yang diberi kapasitas dan fungsi untuk itu. Kontrol searah juga bersifat otomatismekanis yang menuntun perilaku.

Kata Kunci: Eksistensi; Hukum Adat; Pancasila; Pembangunan Hukum.

\section{PENDAHULUAN}

Indonesia adalah negara yang menganut pluralitas dalam bidang hukumnya, dimana ada tiga hukum yang keberadaannya diakui dan berlaku yaitu hukum barat, hukum agama dan hukum adat. Pada prakteknya masih banyak masyarakat yang menggunakan hukum adat dalam mengatur kegiatan sehariharinya serta dalam menyelesaikan suatu permasalahan yang ada. Setiap wilayah di Indonesia mempunyai tata hukum adatnya masing-masing untuk mengatur kehidupan bermasyarakat yang beraneka ragam yang sebagian besar hukum adat tersebut tidak dalam bentuk aturan yang tertulis. Hukum adat tersebut berkembang mengikuti perkembangan masyarakat dan tradisi rakyat yang ada. Hukum adat merupakan endapan kesusilaan dalam masyarakat yang kebenarannya mendapatkan pengakuan dalam masyarakat tersebut.

$$
\text { Pasal 18B ayat (2) UUD } 1945
$$
menyebutkan :

"Negara mengakui dan menghormati kesatuan-kesatuan masyarakat hukum adat beserta hak-hak tradisionalnya sepanjang masih hidup dan sesuai dengan perkembangan masyarakat dan prinsip Negara Kesatuan Republik
Indonesia, yang diatur dalam undang-undang"

Berarti bahwa negara mengakui keberadaan hukum adat serta konstitusional haknya dalam system hukum Indonesia. Undang-undang Nomor 5 Tahun1960 tentang Peraturan Dasar Pokok Agraria yang di undangkan pada tanggal 24 September 1960 adalah berdasarkan Hukum Adat yang dengan tegas dapat dilihat pada pasal 5 yang berbunyi :

"Hukum agraria yang berlaku atas bumi, air dan ruang angkasa ialah hukum adat, sepanjang tidak bertentangan dengan kepentingan nasional dan Negara, yang berdasarkan atas persatuan bangsa, dengan sosialisme Indonesia serta dengan peraturan-peraturan yang tercantum dalam Undang-undang ini dan dengan peraturan perundangan lainnya, segala sesuatu dengan mengindahkan unsur-unsur yang bersandar pada hukum agama."

Pembangunan hukum merupakan upaya membentuk hukum baru guna memperbarui hukum positif. Memperbarui artinya menggantikan hukum-hukum lama dengan hukum yang baru. Pembangunan hukum dalam konteks ini semakna dengan pembaharuan hukum. Sedangkan hukum nasional adalah hukum yang dibangun didasarkan 
pada konstitusi dan Pancasila sebagai dasar negara atau hukum yang dibangun di atas cita rasa dan rekayasa bangsa Indonesia. Pembangunan sistem hukum nasional harus mencakup pembangunan substansi (materi) hukum, struktur atau lembaga hukum juga kultur hukum.

Di dalam Negara Republik Indonesia ini, adat yang dimiliki oleh daerah-daerah serta suku-suku bangsa adalah berbeda-beda, meskipun dasar serta sifatnya adalah satu, yaitu ke Indonesiaan-nya. Oleh karena itu, maka adat bangsa Indonesia itu dikatakan merupakan "Bhinneka" (berbeda-beda di daerah suku-suku bangsanya), "Tunggal Ika" (tetapi tetap satu juga, yaitu dasar dan sifat keindonesiaannya). Dan adat bangsa Indonesia yang "Bhinneka Tunggal Ika" ini tidak mati, melainkan selalu berkembang, senantiasa bergerak serta berdasarkan keharusan selalu dalam keadaan evolusi mengikuti proses perkembangan peradaban bangsanya. (Nunung Nugroho, 2018)

Hubungan antara hukum adat dengan hukum nasional dalam rangka pembangunan hukum nasional adalah hubungan yang bersifat fungsional, artinya hukum adat sebagai sumber utama dalam mengambil bahan-bahan yang diperlukan dalam rangka pembangunan hukum nasional. Hukum adat yang diperlukan dalam era globalisasi atau zaman modem adalah hukum adat yang disesuaikan dengan keadaan dan perkembangan zaman, sehingga hukum adat menunjukkan sifat yang dinamis sehingga dengan mudah dapat berkembang menyesuaikan diri dengan perkembangan zaman karena mempunyai nilai-nilai yang universal maupun lembaga-lembaga hukum yang dalam bentuk pernyataan modern.

Pada dasarnya hukum dipengaruhi oleh kenyataan-kenyataan yang hidup dalam masyarakat itu sendiri. Pengaruh masyarakat terhadap hukum ini dikenal dengan segi realis dari pada hukum. Sebagaimana pandangan Niuwenhuis yang dikutip oleh Mahadi dalam bukunya Soejadi, mengatakan bahwa: peristiwaperistiwa nyata dalam masyarakat memberikan pengaruh kepada hukum. Kita tidak mungkin dapat memenuhi norma-norma hukum, tanpa memikirkan secara mendalam kejadian-kejadian nyata dalam masyarakat, yang hendak diatur oleh norma-norma hukum tersebut. Hukum senantiasa mempunyai hubungan dengan kejadian-kejadian yang nyata dalam masyarakat. (Soejadi, 1999)

Sebagai contoh Keabsahan Gadai Tanah Pertanian Berdasarkan UndangUndang Nomor 56 PRP Tahun 1960, diatur di dalam Pasal 7 mengenai jangka waktu gadai. Jangka waktu gadai menurut undang-undang yaitu 7 tahun lamanya. Jangka waktu tersebut penerima gadai harus mengembalikan tanah pertanian yang menjadi obyek gadai kepada pemberi gadai tanpa penebusan uang gadai, di dalam hukum adat keabsahan gadai tanah pertanian tidak diatur akan tetapi gadai berlangsung atas kesepakatan para pihak.

Hukum adat memandang gadai sebagai hak yang bersifat memberikan kenikmatan yang terjadinya bukan karena adanya perjanjian pinjam meminjam uang 
Nova Yarsina: Eksistensi Hukum Adat Ditinjau Dari Nilai-Nilai Pancasila Dalam...

dan perbuatan hukum lainnya yang menimbulkan hubungan hukum hutang piutang. Pemegang gadai tanah berhak untuk memungut hasil yang ditimbulkan oleh dan dari tanah gadai tersebut, selama itu hasil tanah seluruhnya menjadi hak pemegang gadai, yang merupakan bunga dari utang tersebut. Penebusan tanah itu tergantung pada kemauan dan kemampuan yang menggadaikan. Banyak gadai yang berlangsung bertahun-tahun, berpuluh tahun, bahkan ada pula yang dilanjutkan oleh ahli waris penggadai dan pemegang gadai, karena penggadai tidak mampu untuk menebus tanahnya kembali. Apabila dalam waktu yang ditentukan, pemberi gadai tidak bisa menebusnya, maka dengan sendirinya tanah yang digadaikannya menjadi milik pemegang gadai. (Rachmadi Usman, 2009)

Implikasi Hukum Jika Terjadi Pelanggaran Terhadap Undang-Undang Nomor 56 PRP Tahun 1960, di dalam undang-undang mengatur mengenai sanksi pidana serta denda, sedangkan di dalam hukum adat tidak mengatur mengenai sanksi tetapi diberikan perpanjangan penebusan gadai. Gadai tanah merupakan suatu perjanjian yang menyebabkan tanah diserahkan untuk menerima sejumlah uang tunai, dengan pemufakatan bahwa si penyerah akan berhak mengembalikan tanah itu ke dirinya sendiri dengan jalan membayarkan sejumlah uang yang sama. Sedangkan dalam penjelasan UndangUndang Nomor 56 Prp Tahun 1960 tentang penetapan luas tanah pertanian, defenisi gadai adalah hubungan antara seseorang dengan tanah kepunyaan orang lain yang mempunyai utang uang kepadanya. (Ridwan, 2010)

Gadai tanah merupakan suatu perbuatan pemindahan hak atas tanah kepada pihak lain (yakni pribadi kodrati) yang dilakukan secara terang dan tunai sedemikian rupa, sehingga pihak yang melakukan pemindahan hak mempunyai hak untuk menebus kembali tanah tersebut. Dengan demikian, maka pemindahan hak atas tanah pada gadai bersifat sementara, walaupun terkadang tidak ada patokan tegas mengenai sifat sementara waktu tersebut. (Soerjono Soekanto, 2015)

Gadai yang terjadi di masyarakat saat ini, gadai yang dibuat berdasarkan kesepakatan antara pemberi gadai dan penerima gadai. Perjanjian gadai dibuat secara tertulis maupun tidak tertulis. Mengenai isi gadai biasanya di buat oleh salah satu pihak yakni penerima gadai karena pemberi gadai yang menawarkan diri untuk menggadai tanahnya sehingga penerima gadai menentukan isi gadai tersebut.

Dengan dibuatnya gadai oleh si penerima gadai maka perjanjian tersebut akan menguntungkan salah satu pihak yakni penerima gadai. Melihat hal diatas maka, banyak gadai yang telah berlangsung bertahun-tahun, berpuluh tahun, bahkan ada pula yang dilanjutkan oleh para ahli waris penggadai dan pemegang gadai, karena penggadai tidak mampu untuk menebus tanahnya kembali. Biasanya orang menggadaikan tanahnya hanya bila ia berada dalam keadaan yang sangat mendesak. Praktek gadai tanah yang menyimpang dengan Hukum 
Nasional masih sering terjadi di Indonesia.

\section{METODE PENELITIAN}

Penelitian merupakan terjemahan dari bahasa Inggris yaitu research, yang berasal dari kata re (kembali) dan to search (mencari). Dengan demikian secara logawiyah berarti "mencari kembali". Penelitian merupakan suatu sarana pokok dalam pengembangan ilmu pengetahuan maupun teknologi. Hal ini disebabkan, oleh karena penelitian bertujuan untuk mengungkapkan kebenaran secara sistematis, metodologis, dan konsisten. Melalui proses penelitian tersebut diadakan analisa dan konstruksi terhadap data yang telah dikumpulkan dan diolah (Soerjono Soekanto, Sri Mamudji, 2011). Penelitian ini berjenis penelitian yang bersifat deskriptif analitis (Arikunto, Suharsimi, 2002), yaitu suatu bentuk penelitian yang bertujuan untuk menggambarkan peraturan perundangundangan yang berlaku, dikaitkan dengan dengan teori-teori hukum dan praktek pelaksanaan hukum positif, yang nantinya akan disangkutkan dengan permasalahan yang diteliti dalam karya ilmiah ini. Penelitan deskriptif sendiri merupakan suatu penelitian yang bermaksud memberi gambaran suatu gejala sosial tertentu, suda ada informasi mengenai gejala sosial seperti yang dimaksud dalam permasalahan penelitian, namun merasa belum memadai. Penelitian ini biasanya menjawab apa penjelasan yang lebih terperinci mengenai gejala sosial seperti yang dimaksudkan dalam suatu penelitian yang bersangkutan (Nova Yarsina, 2021).

\section{HASIL DAN PEMBAHASAN}

\section{Eksistensi Hukum Adat Ditinjau Dari Nilai-Nilai Pancasila Dalam Pembangunan Hukum Nasional}

Menurut Sjafirah dan Prasanti (2016), eksistensi di artikan sebagai keberadaan. Dimana keberadaan yang di maksud adalah adanya pengaruh atas ada atau tidak adanya kita. Eksistensi ini perlu "diberikan" orang lain kepada kita, karena dengan adanya respon dari orang di sekeliling kita ini membuktikan bahwa keberadaan atau kita diakui. Masalah keperluan akan nilai eksistensi ini sangat penting, karena ini merupakan pembuktian akan hasil kerja atau performa di dalam suatu lingkungan. Dalam Kamus Umum Bahasa Indonesia, dijelaskan bahwa: "Eksistensi artinya keberadaan, keadaan, adanya" (Idrus, 1996). Selain itu dalam Kamus Besar Bahasa Indonesia dikemukakan bahwa: "Eksistensi; kebendaan, adanya" (Tim Penyusun, 2005).

Eksistensi memiliki makna yang luas cakupannya. Namun, dalam tulisan ini eksistensi yang akan dilihat dari sudut pandang Pembangunan Hukum Nasional yang mengandung nilai-nilai Pancasila dan Hukum Adat. Prinsip yang sangat penting dalam pembangunan Hukum nasional yakni prinsip keberlakuan hukum itu sendiri. Tapi, tidak menutup kemungkinan keberadaan hukum adat tersebut akan tergerus seiring dengan masuknya budaya baru dalam masyarakat hukum adat itu sendiri. Hukum 
Nova Yarsina: Eksistensi Hukum Adat Ditinjau Dari Nilai-Nilai Pancasila Dalam...

adat atau hukum kebiasaan sering di maknai sebagai serangkaian aturan yang mengikat pada suatu masyarakat yang tidak tertulis dan bersumber dari kebiasaan yang tumbuh dan berkembang pada suatu masyarakat tertentu yang kemudian diterima menjadi hukum secara turun temurun. Hukum adat sering pula disebut sebagai hukum yang hidup dalam masyarakat (living law).

Istilah hukum adat adalah merupakan terjemahan dari istilah (bahasa) Belanda Adat Recht yang awalnya dikemukakan oleh Prof. Dr. Christian Snouck Hurgronje nama muslimnya H. Abdul Ghafar di dalam bukunya berjudul De Atjehers yang menyatakan bahwa: Hukum adat adalah adat yang mempunyai sanksi, sedangkan adat yang tidak mempunyai sanksi adalah merupakan kebiasaan normatif, yaitu kebiasaan yang terwujud sebagai tingkah laku dan berlaku di dalam masyarakat. Pada kenyataan antara hukum adat dengan adat kebiasaan itu batasnya tidak jelas (Tolib Setiady, 2009). Pengertian hukum adat menurut Prof. Dr. Cornellis Van Vollenhoven: menyatakan Hukum adat adalah aturanaturan perilaku yang berlaku bagi orang pribumi dan orang-orang timur asing yang disatu pihak mempunyai sanksi (maka dikatakan sebagai hukum) dan di lain pihak tidak dikodifikasikan (maka dikatakan adat) (Tolib Setiady, 2009). Pengertian hukum adat menurut Soejono Soekanto, menyatakan bahwa hukum adat pada hakikatnya merupakan hukum kebiasaan, artinya kebiasaan-kebiasaan yang mempunyai akibat hukum. Kebiasaan yang merupakan hukum adat adalah perbuatan yang diulang-ulang dalam bentuk yang sama (Tolib Setiady, 2009).

Hukum adat merupakan hukum tradisional masyarakat yang merupakan perwujudan dari suatu kebutuhan hidup yang nyata serta merupakan salah satu cara pandangan hidup yang secara keseluruhannya merupakan kebudayaan masyarakat tempat hukum adat tersebut berlaku. Hukum adat juga merupakan nilai-nilai yang hidup dan berkembang di dalam masyarakat suatu daerah

Masyarakat hukum adat hidup sebelum Negara Indonesia terbentuk, nilai-nilai yang ada dalam kehidupan baik secara pribadi dan komunal, menjadi entitas keberadaan keragaman dari bangsa ini yang menjadi satu kesatuan yang tidak terpisahkan.

Pancasila sebagai filsafah dasar kehidupan dalam berbangsa dan bernegara, termasuk bersumber dari hukum adat. Hukum adat menjadi dasar kehidupan masyarakat hukum adat. Hukum Adat diberlakukan oleh Pemerintah Hindia Belanda untuk orangorang Pribumi atau orang-orang Indonesia. Sehubungan dengan pancasila sebagai filsafah dasar dalam kehidupan, keberadaan masyarakat hukum adat, menjadi titik tolak dalam upaya meningkatkan kesejahteraan mereka, seperti diamanatkan dalam UUD NRI 1945.

Hubungan antara hukum adat dengan hukum nasional dalam rangka pembangunan hukum nasional adalah hubungan yang bersifat fungsional, artinya hukum adat sebagai sumber utama 
dalam mengambil bahan-bahan yang diperlukan dalam rangka pembangunan hukum nasional. Hukum adat yang diperlukan dalam era globalisasi atau zaman modem adalah hukum adat yang disesuaikan dengan keadaan dan perkembangan zaman, sehingga hukum adat menunjukkan sifat yang dinamis sehingga dengan mudah dapat berkembang menyesuaikan diri dengan perkembangan zaman karena mempunyai nilai-nilai yang universal maupun lembaga-lembaga hukum yang dalam bentuk pernyataan modern.

Dikaji dari perspektif peraturan perundang-undangan Indonesia saat ini (ius constitutum) terminologi hukum adat dikaji dari perspektif asas, norma, teoretis dan praktik dikenal dengan istilah, "hukum yang hidup dalam masyarakat", "living law", "nilai-nilai hukum dan rasa keadilan yang hidup dalam masyarakat", "hukum tidak tertulis", "hukum kebiasaan", dan lain sebagainya, Selain itu, dari dimensi demikian terminologi hukum adat beserta masyarakat adatnya mempunyai korelasi erat, integral dan bahkan tak terpisahkan yang lazim diungkapkan dalam bentuk petatah petatih. (Lilik Mulyadi, 2013)

Cakupan pembangunan hukum dapat melalui legislasi juga melalui fungsionalisasi hukum yang hidup di masyarakat (the living law). Pembangunan hukum melalui legislasi adalah pembentukan peraturan perundang-undangan atau aturan hukum tertulis. Sedangkan pembangunan hukum melalui fungsionalisasi hukum yang hidup di masyarakat dapat melalui kepatuhan terhadap kebiasaan maupun yurisprudensi.

Usaha pembangunan hukum di Indonesia harus sesuai dengan landasan dan sekaligus tujuan nasional yang ingin diujudkan seperti yang diterangkan dalam UUD 1945 yaitu melindungi segenap bangsa Indonesia, seluruh tumpah darah Indonesia dan untuk memajukan kesejahteraan umum, mencerdaskan kehidupan bangsa, dan ikut melaksakan ketertiban dunia yang berdasarkan perdamaian abadi dan keadilan social.

Pembebanan tanggung jawab untuk memajukan kesejahteraan umum harus berimplikasi terhadap produk hukum yang dibangun. Sebagai implementasi, hukum nasional harus mengabdi kepada kepentingan nasional dan tercapainya kesejahteraan rakyat, keadilan dan ketertiban masyarakat. Hukum sebagai perwujudan nilai-nilai harus mengandung nilai-nilai yang dijunjung tinggi oleh masyarakat Indonesia. Konsep yang dianut oleh Indonesia adalah konsep hukum pembangunan, yaitu menempatkan hukum sebagai sarana pembangunan masyarakat yang Pembangunan hukum nasional harus diarahkan untuk terwujudnya sistem hukum nasional yang mengabdi kepada kepentingan nasional yang materinya bersumber pada cara pandang dan keyakinan bangsa Indonesia. Demikian juga terhadap persoalan baru yang harus direspon oleh kebutuhan hukum yang dibutuhkan untuk mendukung tugas umum pemerintahan dan memajukan kepentingan nasional. 
Nova Yarsina: Eksistensi Hukum Adat Ditinjau Dari Nilai-Nilai Pancasila Dalam...

Arah pembangunan hukum bukan sesuatu yang berdiri sendiri, melainkan terintegrasi dengan arah pembangunan di bidang lainnya memerlukan penyerasian. Betapapun arah pembangunan hukum bertitik tolak pada garis-garis besar gagasan dalam UUD NRI Tahun 1945, dibutuhkan penyelarasan dengan tingkat perkembangan masyarakat yang dimimpikan akan tercipta pada masa depan. Pembangunan hukum tidak identik dan tidak boleh diidentikan dengan pembangunan undang-undang atau peraturan perundangan menurut istilah yang lazim digunakan di Indonesia. Membentuk undang-undang sebanyakbanyaknya, tidak berarti sama dengan membentuk hukum.

Negara hukum bukan negara undangundang. Pembentukan undang-undang hanya bermakna pembentukan norma hukum. Padahal tatanan sosial, ekonomi budaya, dan politik bukan tatanan normatif semata. Karena itulah maka diperlukan ruh tertentu agar tatanan tersebut memiliki kapasitas.

Apabila dilihat dari aspek norma hukum, hal tersebut hanya merupakan salah satu bagian kecil dari kehidupan hukum. Norma hukum merupakan aspek subtansial hukum. Di samping substansi hukum terdapat struktur dan kultur hukum. Struktur merujuk pada institusi pembentukan dan pelaksana hukum (penegak hukum) dan kultur hukum yang merujuk pada nilai, orientasi dan harapan atau mimpi-mimpi orang tentang hukum. Hal yang terakhir ini dapat disamakan dengan secondary rules yang dikonsepkan oleh H. A. L Hart. Esensinya sama, yaitu nilai-nilai, orientasi dan mimpi orang tentang hukum atau hal-hal yang berada di luar norma hukum positif model Hart, memainkan peranan yang amat menentukan bagi kapasitas hukum positif.

Hukum Agraria yang berlaku atas bumi, air dan ruang angkasa ialah hukum adat, sepanjang tidak bertentangan dengan kepentingan nasional dan negara. Hukum Adat yang dijadikan Dasar Hukum Tanah Nasional adalah hukum aslinya golongan rakyat pribumi. Adapun nilai-nilai kearifan lokal hukum adat yang dijadikan dasar dalam pembangunan Hukum Tanah Nasional, meliputi : konsepsi hukum adat tentang tanah, asas-asas hukum adat atas tanah, dan lembaga-lembaga hukum adat yang berkaitan dengan perbuatan hukum di mana tanah sebagai obyeknya.

Gadai tanah adalah merupakan pranata yang muncul dari realisasi kehidupan sosial, yang mengandung nilai hukum dan akan tetapi berada dalam kehidupan manusia yang menggunakannya. (Muhammad Yamin, 2004)

Gadai merupakan salah satu transaksi tanah yang bersumber dari hukum adat yang sering menimbulkan perdebatan dan perselisihan akibat tarik menarik antara Hukum Agraria Nasional dan Hukum Adat. Istilah gadai tanah dikenal juga sebagai menjual gadai, menggadai atau memagang atau pagang gadai (Minangkabau), adol sende (Jawa), ngajual akad/ gade (Sunda), gala (aceh), yaitu perjanjian yang menyebabkan tanah diserahkan untuk menerima tunai sejumlah uang, dengan pemufakatan bahwa si pemilik berhak mengambil tanah 
itu kembali dengan membayar dengan sejumlah uang yang sama. (Ter Haar, 1980)

Dalam sistem hukum adat Minangkabau telah lama dikenal adanya gadai tanah atau pagang gadai, hal ini. disebabkan karena untuk menjual lepas dari tanah itu dalam pewarisan dan sistem matrilineal dilarang, karena tanah adalah salah satu identitas sebagai orang Minang asli.

Undang-Undang Nomor 56/Prp/1960 tentang Penetapan Luas Tanah Pertanian, diatur juga mengenai gadai tanah pertanian. Di mana pada bagian Umum angka 9 (a) dirumuskan bahwa :

Yang dimaksud dengan gadai ialah hubungan antara seseorang dengan tanah kepunyaan orang lain, yang mempunyai utang uang padanya. Selama utang tersebut belum dibayar lunas maka tanah itu tetap berada dalam penguasaan yang meminjamkan uang tadi ("pemeganggadai"). Selama itu hasil tanah seluruhnya menjadi hak pemegang-gadai, yang dengan demikian merupakan bunga dari utang tersebut. Penebusan tanah itu tergantung pada kemauan dan kemampuan yang menggadaikan. Banyak gadai yang berlangsung bertahun-tahun, berpuluh-puluh tahun, bahkan ada pula yang dilanjutkan oleh para ahli-waris penggadai dan pemegang-gadai, karena penggadai tidak mampu untuk menebus tanahnya kembali.

Dalam pada itu di beberapa daerah dikenal pula gadai dimana hasil tanahnya tidak hanya merupakan bunga, tetapi merupakan pula angsuran. Gadai demikian itu disebut "jual angsur".
Berlainan dengan gadai-bisa maka dalam jual-angsur setelah lampau beberapa waktu tanahnya kembali kepada penggadai tanpa membayar (uang tebusan), dalam pasal 7 Undang-Undang Nomor 56/Prp tahun 1960 juga menjelaskan batasan dari gadai tanah itu sendiri, yang berbunyi :

Barang siapa menguasai tanah pertanian mulai berlakunya peraturan ini sudah berlangsung 7 tahun atau lebih wajib mengembalikan tanah itu kepada pemiliknya dalam waktu sebulan setelah tanaman yang ada selesai dengan tidak ada hak untuk menuntut.

\section{Faktor-faktor yang mempengaruhi Eksistensi Hukum Adat Ditinjau Dari Nilai-Nilai Pancasila Dalam Pembangunan Hukum Nasional}

Masyarakat hukum Adat mempunyai keterbatasan dalam lingkungan dan kehidupannya. Harus dipahami keberadaan masyarakat hukum adat mempunyai karekteristik sendiri yang membedakan dengan masyarakat yang lain. Seperti halnya dimana Negara sebagai pemberi sebuah jaminan kepastian hukum adat terhadap masyarakat hukum adat dengan di berlakukannya UU No.5 Tahun 1960 Tentang Peraturan Dasar Pokok Agraria (UUPA) diharapkan dapat mengurangi terjadinya sengketa dan memberikan keadilan untuk masyarakat adat.

Dalam perjalanan sejarah hukum nasional Indonesia, istilah hukum adat (adatrecht) pertama kali diperkenalkan oleh seorang ahli hukum berkebangsaan Belanda bernama Snouck Hurgronje pada tahun 1893 dalam bukunya yang berjudul 
Nova Yarsina: Eksistensi Hukum Adat Ditinjau Dari Nilai-Nilai Pancasila Dalam...

De Atjehers. Pada awalnya, tidak banyak orang yang mengenal istilah ini. Namun, sejak van Vollenhoven mempopulerkan adatrecht dalam bukunya Het Adatrecht van Nederland-Indie, istilah ini menjadi dikenal luas di kalangan akademisi. Menurut Van Vollenhoven, hukum adat adalah hukum yang tidak bersumber kepada peraturanperaturan yang dibuat oleh pemerintah Hindia Belanda dahulu atau alat-alat kekuasaan lainnya yang menjadi sendirinya dan diadakan sendiri oleh kekuasaan Belanda, dan berlaku bagi orang-orang pribumi dan orang-orang Timur Asing. Selanjutnya beliau berpendapat bahwa untuk membedakan antara adat dan hukum adat dilihat dari unsur sanksi, sehingga tidak semua adat merupakan hukum adat. Hanya adat yang bersanksi, yang dapat digolongkan sebagai hukum adat. Maksud sanksi di sini adalah apabila dilanggar ada akibatnya dan mereka yang melanggar dapat dituntut dan kemudian dihukum.

Pandangan dari Ter Haar, yang menyatakan bahwa hukum adat adalah seluruh peraturan yang diterapkan dalam keputusan-keputusan yang penuh wibawa dan dalam kelahirannya dinyatakan mengikat. Pendapat ini terkenal dengan teori keputusan (beslissingenleer). Dengan demikian hukum adat lahir dari dan dipelihara oleh keputusan-keputusan para warga masyarakat umum. Lebih dari itu, keputusan-keputusan fungsionaris hukum, bukan hanya yang dihasilkan oleh hakim, tetapi juga termasuk keputusan kepala adat, rapat desa, wali tanah dan petugas-petugas desa lainnya. Keputusan tersebut juga tidak hanya yang merupakan keputusan mengenai sengketa resmi, tetapi juga meliputi keputusan yang berdasarkan nilai-nilai hidup yang berlaku dalam alam kemasyarakatan anggotaanggota persekutuan.

Kedudukan hukum adat selaku materi ialah memberi bahan untuk pembinaan hukum nasional Indonesia. Hukum Adat sebagai bagian dari Hukum Positip, selain memerlukan pembinaan yang diarahkan kepada Kesatuan Bangsa dan perkembangan pembangunan, sebagai hukum yang hidup dan dengan demikian sebagai hukum yang sesuai dengan pandangan hidup, cita-cita dan kesadaran hukum Rakyat merupakan salah satu sumber yang penting untuk memperoleh bahan-bahan bagi pembangunan hukum nasional yang baru. Adapun hubungannya dengan masalah perundang-undangan adalah, bahwa pembangunan hukum nasional kita, dengan tidak mengabaikan timbul dan tumbuh serta berkembangnya hukum kebiasaan, terutama akan dilakukan melalui pembuatan peraturanperaturan perundangan. Sehingga dapat disimpulkan bahwa perkembangan hukum positif di Indonesia tidak terlepas dari peranan hukum adat dalam memberikan nilai-nilai serta pandangan-pandangan maupun cita-cita masyarakat terhadap pembangunan hukum nasional, yang mana hukum adat tersebut diterapkan ke dalam peraturan-perundang-undangan sebagai sumber hukum.

Hukum merupakan tindakan atau kegiatan yang dimaksudkan untuk membentuk kehidupan hukum ke arah yang lebih baik dan kondusif. Sebagai 
bagian dari pembangunan nasional, pembangunan hukum harus terintegrasi dan bersinergi dengan pembangunan bidang lain, serta memerlukan proses yang berkelanjutan. Pelaksanaan pembangunan hukum tidak hanya ditujukan untuk hukum dalam arti positif yang identik dengan peraturan perundangundangan, tetapi juga hukum dalam arti yang luas yang menunjuk pada sebuah sistem, yang meliputi pembangunan materi hukum, pembangunan kelembagaan dan penegakan hukum, pembangunan pelayanan hukum dan pembangunan kesadaran hukum masyarakat. Karena unsur-unsur tersebut saling mempengaruhi, hukum harus dibangun secara simultan, sinkron, dan terpadu.

Adapun hukum nasional yaitu hukum atau peraturan perundang-undangan yang didasarkan kepada landasan ideologi dan konstitusi negara, yakni Pancasila dan UUD NRI 1945. Menurut Barda Nawawi Arief, apabila sistem hukum nasional dilihat sebagai substansi hukum, maka sistem hukum nasional adalah sistem hukum Pancasila. Sistem hukum nasional harus berorientasi pada tiga pilar: a. Berorientasi pada nilai b. Berorientasi pada nilai c. Berorientasi pada nilai- $\mathrm{k}$, demokratik, berkeadilan social Bernard Arief Sidharta berpendapat bahwa tatanan hukum nasional harus mengandung enam ciri;

a. Berwawasan kebangsaan dan nusantara;

b. Mampu mengakomodasi kesadaran hukum kelompok etnis kedaerahan dan keyakinan keagamaan; c. Sejauh mungkin berbentuk tertulis dan terunifikasi;

d. Bersifat rasional yang mencakup rasionalitas efisiensi, rasionalitas kewajaran, rasionalitas kaidah, dan rasionalitas nilai;

e. Aturan prosedural yang menjamin transparansi, yang memungkinkan kajian rasional terhadap proses pengambilan putusan oleh pemerintah; f. Responsive terhadap perkembangan aspirasi dan ekspektasi masyarakat.

Eeksistensi Hukum Adat dalam Penyelenggaraan Tatanan Kemasyarakatan telah ada sejak lama, aturan hukum yang mengakomodir dan melegalkan Hukum Adat dalam penyelenggaraan tatanan kemasyarakatan telah ada dan berstrata dari mulai tingkat Hukum Dasar (konstitusi) sampai aturan yang operasional untuk pengimplementasiannya, ada yang mengaplikasikan secara langsung ada yang secara tidak langsung, tergantung pada karakteristik tempat dan waktu dimana Hukum Adat diterapkan.

Hukum Adat pada umumnya belum atau tidak tertulis yaitu kompleks norma-norma yang bersumber pada perasaan keadilan rakyat yang selalu berkembang meliputi peraturan tingkah laku manusia dalam kehidupan seharihari, senantiasa ditaati dan dihormati karena mempunyai akibat hukum atau sanksi. Dari definisi di atas, dapat disimpulkan bahwa Hukum Adat merupakan sebuah aturan yang tidak tertulis dan tidak dikodifikasikan, namun tetap ditaati dalam masyarakat 
Nova Yarsina: Eksistensi Hukum Adat Ditinjau Dari Nilai-Nilai Pancasila Dalam...

karena mempunyai suatu sanksi tertentu bila tidak ditaati. Dari pengertian Hukum Adat yang diungkapkan diatas, bentuk Hukum Adat sebagian besar adalah tidak tertulis. Padahal, dalam sebuah negara hukum, berlaku sebuah asas yaitu asas legalitas. Asas legalitas menyatakan bahwa tidak ada hukum selain yang dituliskan di dalam hukum. Hal ini untuk menjamin kepastian hukum. Namun di suatu sisi bila hakim tidak dapat menemukan hukumnya dalam hukum tertulis, seorang hakim harus dapat menemukan hukumnya dalam aturan yang hidup dalam masyarakat. (Marco Manarisip, 2012) Sejak Indonesia berdiri sebagai negara berdaulat, hukum adat menempati perannya sendiri dan dalam perkembangannya, hukum adat justru mendapat tempat khusus dalam pembangunan hukum nasional. Dalam beberapa tahun belakangan di dalam pembentukan hukum negara pun, kebiasaan-kebiasaan (sering disebut kearifan lokal) yang hidup dalam masyarakat menjadi salah satu pertimbangan penting dalam pembentukan hukum negara, baik pada pembentukan undang-undang maupun dalam pembentukan peraturan daerah. Konsep pluralisme hukum tidak lagi tidak berkembang dalam ranah dikotomi antara sistem hukum negara (state law) di satu sisi dengan sistem hukum rakyat (folk law) dan hukum agama (religius law) di sisi yang lain. Pada tahap perkembangan ini, konsep pluralisme hukum lebih menekankan pada interaksi dan ko-eksistensi berbagai sistem hukum yang mempengaruhi bekerjanya norma, proses, dan institusi hukum dalam masyarakat. (Sudirman, Ahyuni Yunus, Mohammad Arif, 2021)

Di Sumatera Barat (Minangkabau), khususnya dalam Penerapan Gadai mengaplikasikan Hukum Adat secara langsung, dampak penerapan Hukum Adat dalam penyelenggaraan gadai pada faktor sikap dan prilaku warga masyarakat, sehingga warga masyarakat merasa ikut bertanggungjawab terhadap terselenggaranya penyelenggaraan Gadai dan Masyarakat sampai sekarang mematuhi aturan Hukum Adat tersebut. Secara teoritis, hak milik dengan hak menguasai berbeda. Pemegang hak milik atas suatu benda pastilah pemilik dari benda tersebut sedangkan pemegang hak menguasai belum tentu pemilik benda itu, bila dikaitkan dengan hak ulayat, maka hak ulayat termasuk kategori hak menguasai. Karena hak ulayat merupakan kepunyaan bersama masyarakat hukum adat dimana penguasanya dipimpin oleh penguasa adat. (Nova Yarsina, 2018)

\section{KESIMPULAN}

1. Bangsa Indonesia sudah berhasil melakukan reformasi hukum terhadap konstitusi. Reformasi hukum harus berlanjut dengan pembentukan dan pembaruan hukum menggantikan hukum peninggalan Belanda. Memiliki hukum sendiri bagi bangsa Indonesia dapat menampakkan jati diri bangsa. Pembangunan hukum secara sederhana mengandung pengertian upaya melakukan perbaikan dari kondisi yang kurang 
baik menuju ke arah yang lebih baik. Menurut pengertian ini pembangunan bisa semakna dengan pembaharuan. Pembaharuan (reform) merupakan upaya untuk melakukan reorientasi dan reformasi terhadap sesuatu hal yang akan ditempuh melalui kebijakan.

2. Pembangunan hukum nasional merupakan proses membangun suatu tata hukum beserta perangkatnya. Pembangunan hukum nasional harus mampu mengganti semua hukum produk Kolonial Belanda diganti dengan hukum produk sendiri. Pembangunan hukum tidak dapat lepas dari politik hukum, karena sebagai arah dalam pembuatan dan penegakan hukum guna mencapai cita-cita dan tujuan nasional. Hukum seperti yang disebutkan di dalam Oxford English Dictionary yaitu kumpulan aturan baik sebagai hasil pengundangan formal maupun kebiasaan, di mana suatu negara atau masyarakat tertentu mengaku terikat sebagai anggota atau sebagai subyeknya. Hukum merupakan sebuah sistem pengawas perilaku (ethical control). Wujud hukum berupa norma yang merupakan produk dari suatu pusat kekuasaan yang memiliki kewenangan untuk menciptakan dan menerapkan hukum. Hukum sebagai suatu sistem kontrol searah yang dilakukan oleh suatu central organ yang memiliki kekuasaan. Kontrol searah mengandung pengertian bahwa kontrol hanya berlangsung dari suatu organ tertentu yang diberi kapasitas dan fungsi untuk itu. Kontrol searah juga bersifat otomatis-mekanis yang menuntun perilaku. Keanekaragaman system Adat perlu disikapi sebagai suatu realitas sosial yang memberi petunjuk bagi pembuat aturan hukum agar lebih hati-hati dalam hal pembuat aturan perihal tatanan kemasyarakatan khususnya masyarakat desa di Indonesia sehingga di satu sisi tidak menimbulkan dampak yang dirasa kurang tepat oleh masyarakat, disisi lain juga harus tetap dalam koridor mempertahankan aturanaturan sesuai dengan kebutuhan kesinambungan Negara Kesatuan Republik Indonesia. Bila terjadi hambatan berupa perbedaan norma hukum Negara dengan Hukum Adat antisipasinya adalah sinkkronisasi. Eksistensi hukum adat dalam tatanan kehidupan masyarakat timbul sebagai wujud adanya keinginan untuk menempatkan tatanan hukum adat pada proporsi ideal dalam system hukum nasional, ditengah aktualitas dan perkembangan hukum modern

\section{DAFTAR PUSTAKA}

\section{Buku dan Jurnal}

Soejadi, 1999, Pancasila sebagai Sumber Tertib Hukum Indonesia Yogyakarta: Lukman Offset

Rachmadi Usman, 2009, Hukum Jaminan Keperdataan, Jakarta : Sinar Grafika

Ridwan, 2010, Pemilikan Rakyat Dan Negara Atas Tanah Menurut Hukum Pertanahanm Indonesia Dalam Perspektif Hukum Islam, 
Nova Yarsina: Eksistensi Hukum Adat Ditinjau Dari Nilai-Nilai Pancasila Dalam...

Jakarta, Cet. I; Badan Litbang Dan

Diklat Kementerian Agama RI

Soerjono Soekanto, 2015, Hukum Adat

Indonesia, Jakarta, Cet. XIIV,

Rajawali Pers

Muhammad Yamin, 2004, Gadai Tanah

Sebagai Lembaga Pembiayaan

Rakyat Kecil, Medan : Pustaka

Bangsa Press

Ter Haar, 1980, Asas-Asas dan Susunan

Hukum Adat, Terjemahan oleh K.

Ng. Soebakti Poesponoto, Jakarta:

Pradnya Paramita

Nunung Nugroho, 2018, Hukum Adat

Dalam Perspektif Pembangunan

Hukum Nasional Berbasis

Pancasila, Jurnal Spektrum

Hukum, Vol. 15/No. 2/Oktober 2018

Nova Yarsina, 2018, Perlindungan

Hukum Terhadap Tanah Ulayat

Yang Telah Bersertifikat Di Kota

Bukittinggi. Jurnal Cendekia

Hukum: Vol. 3, No 2, Maret 2018

Marco Manarisip, 2012, Eksistensi Pidana

Adat Dalam Hukum Nasional,

Jurnal Lex Crimen Vol.I/No.4/Okt-

Des/2012

Nova Yarsina, 2018, Hak Konstitusional

Atas Air Pasca Dihapusnya
Undang Undang Nomor 7 Tahun 2004 Tentang Sumber Daya Air oleh Mahkamah konstitusi, Jurnal Ensiklopedia Social Review Vol. 3 No.2 Juni 2021

Lilik Mulyadi, 2013, Eksistensi Hukum Pidana Adat Di Indonesia Pengkajian Asas, Norma, Teori, Praktik dan Prosedurnya Jurnal Hukum dan Peradilan, Volume 2 Nomor 2 Juli 2013

Sudirman, Ahyuni Yunus, Mohammad Arif, 2021, Implementasi NilaiNilai Hukum Adat Dalam Mewujudkan Hukum Yang Bersendikan Kearifan Lokal, Journal of Lex Generalis JLG), Vol.2, No. 1,Januari 2021

\section{Peraturan Perundang-Undangan}

Undang-Undang Dasar 1945

Undang-undang Nomor 5 Tahun1960 tentang Peraturan Dasar Pokok Agraria

Undang-Undang Nomor 56 PRP Tahun 1960 